\title{
Coherence Between Degree of Hypertension and Incidence of Acute Coronary Syndrome in Cardiac Departement of Dustira Cimahi Hospital
}

\author{
Yusron Iriawan* \\ Department of Internal Medicine, Medical Faculty \\ Universitas Jenderal Achmad Yani \\ Cimahi, Indonesia \\ *yusron.iriawan@fk.unjani.ac.id \\ Yanti Nurrokhmawati \\ Department of Otorhinolaryngology, Medical Faculty \\ Universitas Jenderal Achmad Yani \\ Cimahi, Indonesia
}

\author{
Nanda Maulana \\ Medical Faculty \\ Universitas Jenderal Achmad Yani \\ Cimahi, Indonesia \\ Danial Ahmad Dzulfikri \\ Medical Faculty \\ Universitas Jenderal Achmad Yani \\ Cimahi, Indonesia
}

\begin{abstract}
Acute coronary syndrome (ACS) is a syndrome consist of several coronary disease such as unstable angina pectoris (UAP), non-ST-elevation myocardial infarction (NSTEMI), and ST- elevation myocardial infarction (STEMI). ACS risk factors are devided into two main categories, the conventional risk factors and recently known atherothrombosisassociated risk factors. Hypertension is one of ACS major risk factors. This study aims to determine the Coherence of the stage of hypertension with the incidence of ACS in the Cardiac Inpatient Room Dustira Cimahi Hospital in 2018. This study was an analytical study with a cross-sectional method approach, the population in this study were all ACS patients that recorded in medical record, while the respondents were ACS patients with a history of hypertension recorded in medical record and treated at Dustira Cimahi Hospital with total 112 samples, by using systematic random sampling. Based on the research, there were 48 men patients $(42.90 \%)$, while femen patients were 64 $(57.10 \%)$. The average age of patients was 61.75 years old. Obtained from 19 people with normal-high blood pressure degree, 10 people $(52.63 \%)$ were ACS-UAP, from 24 patients with first stage of hypertension as many as 15 people $(62.50 \%)$ were ACS-UAP, from 29 patients with second stage of hypertension as many as 18 people $(62.07 \%)$ were ACS NSTEMI, and from 40 patients with third stage of hypertension as many as 29 people $(\mathbf{7 2 . 5 0 \%})$ were ACS STEMI. A p-value of 0.000 showed a significant Coherence between the stage of hypertension and the incidence of acute coronary syndrome at Dustira Hospital Cimahi in 2018.
\end{abstract}

Keywords-acute coronary syndrome, stage of hypertension

\section{INTRODUCTION}

Hypertension or high blood pressure is a syndrome or a progressive collection of cardiovascular symptoms as a result of other complex and interrelated conditions according to the American Society of Hypertension (ASH) [1]. Based on the European Society of Cardiology (ESC) / European Society of Hypertension (ESH) Hypertension Guidelines 2018 in the 2019 Hypertension Management Consensus of the Indonesian Hypertension Doctors Association (PERHI), hypertension is an increase in blood pressure $\geq 140 / 90 \mathrm{mmHg}$, whereas clinically hypertension can be defined as an increase in blood pressure that requires therapy to reduce mortality and morbidityv [2]. Persistence can cause damage to the kidneys (kidney failure), heart (coronary heart disease), and brain (causing stroke) if not detected early and received adequate treatment [1].

World Health Organization (WHO) data in 2011 shows that one billion people in the world suffer from hypertension, 2/3 of whom are in low to medium income developing countries. Hypertension cases that occurred at the age of 55-64 years amounted to $17.2 \%$, followed by age $45-54$ years at $11.9 \%$, and at the age of $35-44$ years by $6.3 \%$. Meanwhile, based on economic status, the proportion of hypertension mostly occurred at the lower middle level $(27.2 \%)$ and medium level $(25.9 \%)$ [3,4]. The prevalence of national hypertension based on Riskesdas 2013 was $25.8 \%$, then from the latest data, Riskesdas in 2018 there was an increase to $34.1 \%$ and the highest was in the Bangka Belitung Islands (30.9\%), while the lowest was in Papua (16.8\%). Based on these data, of the $25.8 \%$ of people who have hypertension only $1 / 3$ are diagnosed, and the rest are undiagnosed. West Java is the only province that did not experience a decrease in the prevalence rate of hypertension from 2007 to 2013 , which was $30.0 \%$. The city of Cimahi has a hypertension prevalence rate of $2.96 \%$ taken from data from the West Java Provincial Health Office in 
2016. Riskesdas data for 2018 showed $8.8 \%$ of people diagnosed with hypertension took antihypertensive drugs $[3,4]$.

Hypertension can be classified into two types, namely essential or primary hypertension, the cause of which is not known, which is usually hereditary and is influenced by the interaction between genetic and environmental factors. Secondary hypertension can be caused by kidney disease, endocrine disease, heart disease, and kidney / adrenal gland disorders. This disease often causes no symptoms, while persistently high blood pressure for a long time can cause various complications, one of which is Acute Coronary Syndrome (ACS) which causes hypertension, which is often referred to as the silent killer. The classification of blood pressure measurement results according to the ESC / ESH Hypertension Guidelines 2018 is divided into optimal, namely $<120 /<80 \mathrm{mmHg}$, normal that is $<130 /<85 \mathrm{mmHg}$, normal high with blood pressure 130-139 / 85-89 mmHg, 1st degree hypertension, namely 140-159 / 90-99 $\mathrm{mmHg}$, hypertension grade 2 is $160-179 / 100-109 \mathrm{mmHg}$, and hypertension grade 3 is $\geq 180 / \geq 110 \mathrm{mmHg}[2,5,6]$.

ACS is a major cardiovascular problem because it causes a high mortality rate. ACS is a syndrome consisting of several coronary diseases, namely Unstable Angina Pectoris (UAP), non-ST-elevation myocardial infarction (NSTEMI) and STelevation myocardial infarction (STEMI). The risk factors for ACS are divided into two major groups, namely conventional risk factors and new known risk factors related to the atherothrombotic process. Based on conventional risk factors, there are four biological risk factors that cannot be changed, namely age, sex, race, and family history. Hypertension is one of the major risk factors for ACS apart from smoking, hyperlipidemia, diabetes mellitus, lack of physical activity, and obesity. In epidemiological studies conducted on NSTEMI patients, chronic hypertension was the most common risk factor detected, accounting for nearly $2 / 3$ of the entire population $[7,8]$.

According to WHO in 2008, ischemic heart disease is the leading cause of death in the world (12.8\%), but this case ranks third as a cause of death in Indonesia. SKA is still a significant public health problem in industrialized and developing countries. This syndrome is one of the causes of hospitalization in the United States, with a total of 1.36 million cases, of which 0.81 million are myocardial infarction, and the rest are unstable angina pectoris $[9,10]$.

Based on the results of research on the degree of hypertension on the incidence of ACS carried out at the Internal Medicine Department of Bethesda Tomohon Hospital in November-December 2013, it was obtained from 44 patients diagnosed with ACS, as many, as 7 people did not have a history of hypertension (15.9\%), 9 people were prehypertensive. (20.5\%), 9 people with grade 1 hypertension (20.5\%), and 19 people with grade 2 hypertension $(43.2 \%)$. Based on the number, STEMI is the most cases, followed by NSTEMI, and finally unstable angina pectoris (APTS). Increased systolic and diastolic blood pressure increases the risk of developing ACS. Individuals with blood pressure above $160 / 95 \mathrm{mmHg}$ have a 2-3 times greater risk of developing ACS [11].

Based on the explanation above, it is known that hypertension is one of the major risk factors for ACS, which is most commonly detected by almost $2 / 3$ of the entire population, and grade 2 hypertension occurs in $43.2 \%$ of cases. From the data from the Cimahi City Health Office in 2018, there are around 100 people/month who experience SKA at Dustira Hospital.

\section{RESEARCH METHODS}

The research to be conducted is an analytical study with a cross-sectional study approach of patients diagnosed with ACS using secondary data in the form of patient medical records.

In this study, the population was all medical records of ACS patients, while the research subjects were medical records of ACS patients with a history of hypertension and were treated in the Cardiac Inpatient Room of Dustira Cimahi Hospital in 2018.

The exclusion criteria in this study were incomplete medical records, patients who had a history of diabetes, obesity, and stable angina pectoris. The sampling method used in this study is a purposive sampling technique, which is sampling taken randomly from a list of medical record numbers that are by the inclusion and exclusion criteria by applying multiple systems that have been determined until the number of samples meets the minimum requirement. 96 samples. The variables studied were independent variables of the degree of hypertension and the dependent variable on the incidence of ACS. The univariable analysis aims to describe the characteristics of research subjects including age, gender, degree of hypertension, the incidence of acute coronary syndrome in the Cardiac Inpatient Room of Dustira Cimahi Hospital in 2018. The data is presented in numbers and percentages for categorical data and the data are presented in mean, standard deviation, median, minimum and maximum values for numeric data.

Bivariable analysis to examine the Coherence between the degree of hypertension and the incidence of acute coronary syndrome in the Cardiac Inpatient Room of Dustira Cimahi Hospital in 2018 used the Chi-Square test because the two variables were categorical data types.

Data analysis was performed using the Statistical Product and Service Solution (SPSS) program for Windows version 18.0 at $95 \%$ confidence level and $p$-value $\leq 0.05$.

\section{RESULTS AND DISCUSSION}

This research aims to study the coherence between degree of hypertension with the incidence of the Acute coronary syndrome in the Cardiac Inpatient Room Dustira Cimahi Hospital in 2018. There were 112 subject medical records that 
met the study inclusion criteria of a total of 1,580 ACS patients in 2018.

The description of SKA patients in the Cardiac Inpatient Room of the Dustira Cimahi Hospital in 2018 based on gender using the frequency distribution and percentage can be seen in table 1 .

TABLE I. CHARACTERISTICS OF RESPONDENTS BY GENDER

\begin{tabular}{|l|c|c|}
\hline \multicolumn{1}{|c|}{ Gender } & Frequency (n) & Persentage (\%) \\
\hline Men & 48 & 42,90 \\
\hline Women & 64 & 57,10 \\
\hline Total & 112 & 100,00 \\
\hline
\end{tabular}

Table 1 shows that patients in the Cardiac Inpatient Room of the Dustira Cimahi Hospital in 2018 were women with a total of 64 people $(57.1 \%)$ and men with a total of $48(42.9 \%)$ more women than men. Based on Wahyuni and Eksanoto's research, women tend to suffer from hypertension compared to men. In this study, $27.5 \%$ of women had hypertension, while for men it was only $5.8 \%$ [12].

The risk of hypertension in women increases starting from the pre-menopausal period. Women who have not entered menopause are protected by the hormone estrogen which plays a role in increasing the levels of High-Density Lipoprotein (HDL). In the pre-menopausal period, women begin to lose little by little the hormone estrogen, which has been protecting blood vessels from damage. The process continues where there is a change in the quantity of estrogen according to a woman's age naturally. As a result of reduced HDL levels and high LDL cholesterol (Low-Density Lipoprotein) in menopausal women, this can affect the atherosclerosis process which in turn can cause an increase in blood pressure [13-16].

Apart from gender, the characteristics of the patient's age also influence the occurrence of hypertension and ACS. The description of acute coronary syndrome patients in the Cardiac Inpatient Room of Dustira Cimahi Hospital in 2018 based on age can be seen in table 2 .

TABLE II. CHARACTERISTICS OF RESPONDENTS BY AGE

\begin{tabular}{|l|c|c|c|c|}
\hline & Minimum & Maximum & Mean & Std. Deviation \\
\hline Age (year) & 26,00 & 80,00 & 61,75 & 9,33 \\
\hline
\end{tabular}

Table 2 shows the average age of Cardiac Inpatients at Dustira Cimahi Hospital in 2018, namely 61.75 years, with a minimum age of 26 years and a maximum age of 80 years. Based on research conducted by Rahajeng and Tumirah, at the age of 60-64 years there is an increased risk of hypertension by 2.18 times, at age 65-69 years by 2.45 times, and at age $>70$ years by 2.97 times [17].

Blood pressure in the elderly will tend to be high so that they are more at risk of developing hypertension. As you age, your blood pressure tends to increase due to thickening of the artery walls, which in turn causes your blood vessels to narrow and become stiff. In this condition the large arteries will then lose their flexibility and become stiffer so that the blood at each heart beat is forced to pass through the blood vessels that are narrower than usual and can cause a rise in blood pressure [18].

TABLE III. CHARACTERISTICS OF RESPONDENTS BASED ON BLOOD PRESSURE

\begin{tabular}{|l|c|c|c|c|}
\hline \multicolumn{1}{|c|}{$\begin{array}{c}\text { Blood } \\
\text { pressure }\end{array}$} & Minimum & Maximum & Mean & $\begin{array}{c}\text { Std. } \\
\text { Deviation }\end{array}$ \\
\hline $\begin{array}{l}\text { Systolic blood } \\
\text { pressure }\end{array}$ & 130,00 & 212,00 & 163,43 & 24,96 \\
\hline $\begin{array}{l}\text { Diastolic blood } \\
\text { pressure }\end{array}$ & 70,00 & 120,00 & 92,73 & 9,90 \\
\hline
\end{tabular}

Table 3 shows the average systolic blood pressure of the Cardiac Inpatient at Dustira Cimahi Hospital in 2018, namely $163.43 \mathrm{mmHg}$, with a minimum systolic blood pressure of 130 $\mathrm{mmHg}$ and a maximum of $212 \mathrm{mmHg}$. The average diastolic blood pressure of the Cardiac Inpatient at Dustira Cimahi Hospital in 2018 was $92.73 \mathrm{mmHg}$, with a minimum diastolic blood pressure of $70 \mathrm{mmHg}$ and a maximum of $120 \mathrm{mmHg}$.

In the study, it was shown that the patient's average blood pressure was classified as hypertensive. This is consistent with Torry's research which showed that there were more ACS patients with hypertension than pre-hypertension [19]. Hypertension is one of the main factors causing atherosclerosis and the development of plaques that are unstable and prone to rupture, which in turn causes thrombosis and occlusion of vessels. Blood that can develop into SKA [8].

The description of the degree of hypertension and acute coronary syndrome in patients in the Cardiac Inpatient Room of Dustira Cimahi Hospital in 2018 using frequency and percentage distributions can be seen in tables 4 and 5 .

TABLE IV. DESCRIPTION OF HYPERTENSION DEGREES IN THE CARDIAC INPATIENT ROOM OF DUSTIRA CIMAHI HOSPITAL IN 2018

\begin{tabular}{|l|c|c|}
\hline Degree of hypertension & Frequency (n) & Percentage (\%) \\
\hline Normal-High & 19 & 17,00 \\
\hline Hypertension grade I & 24 & 21,40 \\
\hline Hypertension grade II & 29 & 25,90 \\
\hline Hypertension grade III & 40 & 35,70 \\
\hline Total & 112 & 100,00 \\
\hline
\end{tabular}

Table 4 shows the degree of hypertension of patients in the Cardiac Inpatient Room of the Dustira Cimahi Hospital in 2018, most of them were included in grade III hypertension with a total of 40 people $(35.70 \%), 29$ people $(25.90 \%)$ grade II hypertension as many as 24 people $(21.40 \%)$, and normalhigh as many as 19 people $(17.00 \%)$.

In the study, it was found that patients with the most conditions were grade III hypertension, while the least was normal-high. This is by the results of research conducted at the Internal Medicine Department / SMF of Bethesda Tomohon Hospital in November-December 2013, where 44 patients were diagnosed with ACS, as many as 7 people did not have a 
history of hypertension (15.9\%), 9 people were prehypertensive $(20.5 \%)$, 9 people with grade 1 hypertension (20.5\%), and 19 people with grade 2 hypertension $(43.2 \%)$ [11].

Based on the existing theory, hypertension is a risk factor for the acute coronary syndrome. Any increase in systolic blood pressure of $10 \mathrm{mmHg}$ or an increase in diastolic blood pressure of $5 \mathrm{mmHg}$ can increase the risk of ACS. So it can be said that the higher a person's blood pressure, the higher the risk of developing ACS [20].

Pathophysiologically, the coherence between hypertension and ACS occurs due to an atherosclerotic process that is influenced by the influx of LDL cholesterol in the intima of blood vessels that exceeds normal levels, LDL cholesterol will be oxidized when it reacts with free oxygen molecules formed from various enzymatic and nonenzymatic reactions, then cholesterol. Oxidized LDL will trigger adhesion and entry of monocytes and $\mathrm{T}$ lymphocytes into the intima of blood vessels through the endothelial surface, macrophages are formed from monocytes and will phagocyte oxidized LDL cholesterol, thus forming foam cells which in turn trigger the release of cytokines such as interferon- $\gamma$, tumor necrosis factor- $\alpha$, and interleukin-1 resulting in atherosclerosis which causes the lumen of the blood vessels to shrink so that there is an increase in total systemic vascular resistance which aggravates hypertension so that ACS can occur [21].

In a study conducted at RSU Bethesda Tomohon, a classification of hypertension was used based on JNC VII, where the highest degree of blood pressure was grade II hypertension with the highest number of incidents. The results of the research conducted at the Dustira Hospital showed the same thing, where the most subjects were the subjects with the highest degree of blood pressure according to ESC / ESH, namely grade III hypertension. Based on the results, it was found that most subjects belonged to grade III hypertension which had a higher comorbid than normal-high, grade I hypertension, and grade II hypertension. The higher a person's blood pressure, the narrower the walls of the blood vessels, which in turn will become stiffness.
TABLE V. DESCRIPTION OF ACUTE CORONARY SYNDROME IN THE CARDIAC INPATIENT ROOM OF DUSTIRA CIMAHI HOSPITAL IN 2018

\begin{tabular}{|l|c|c|}
\hline \multicolumn{1}{|c|}{$\begin{array}{c}\text { Acute Coronary } \\
\text { Sindrome }\end{array}$} & Frequency (n) & Percentage (\%) \\
\hline UAP & 37 & 33,00 \\
\hline NSTEMI & 34 & 30,40 \\
\hline STEMI & 41 & 36,60 \\
\hline Total & 112 & 100,00 \\
\hline
\end{tabular}

Table 5 shows the incidence of acute coronary syndrome in patients with Cardiac Inpatient Care at Dustira Cimahi Hospital in 2018, the most were STEMIs with 41 people (36.60\%), UAP 37 people $(33.00 \%)$, and NSTEMI as many as 34 people. $(30.40 \%)$. This is following the research conducted by Halimuddin regarding blood pressure with the incidence of the acute coronary syndrome (ACS) STEMI patients with 21 people $(63.3 \%)$, NSTEMI 6 people $(18.1 \%)$, and UAP 6 $(18.1 \%)$ [22].

The occurrence of SKA can develop from UAP to NSTEMI to STEMI. Acute coronary syndrome with STsegment elevation occurs when a coronary artery thrombus occurs rapidly at the site of vascular injury that can be triggered by factors such as smoking, hypertension, and lipid accumulation. In most cases, infarction occurs when the atherosclerotic plaque is fissured, ruptured, or ulcerated and if a local or systemic condition triggers thrombogenesis, resulting in mural thrombus at the site of rupture resulting in coronary artery occlusion. In STEMI the classic pathological picture consists of a fibrin-rich red thrombus, which tends to rupture easily because it has a thin fibrous cap and a lipid-rich core. Furthermore, at the site of plaque rupture, collagen, ADP, epinephrine, and serotonin are released which trigger platelet activation, which in turn will produce and release thromboxane $\mathrm{A} 2$ as a potent local vasoconstrictor. Platelet activity also triggers conformational changes to the glycoprotein IIb / IIIa receptor so that it has a high affinity for amino acid sequences in soluble adhesion proteins (integrins) such as fibrinogen and von Willebrand factor (vWF) which can bind two different platelets simultaneously, resulting in cross-linking, platelets and aggregation [21].

The coherence between the degree of hypertension and the incidence of acute coronary syndrome in the Cardiac Inpatient Room of Dustira Cimahi Hospital in 2018 was analyzed using the chi-square test statistic which can be seen in table 6 . 
TABLE VI. THE COHERENCE BETWEEN THE DEGREE OF HYPERTENSION AND THE INCIDENCE OF ACUTE CORONARY SYNDROME IN THE HEART INPATIENT ROOM AT THE DUSTIRA CIMAHI HOSPITAL IN 2018

\begin{tabular}{|c|c|c|c|c|c|c|c|c|c|c|}
\hline \multirow{3}{*}{\multicolumn{2}{|c|}{ Variable }} & \multicolumn{6}{|c|}{ Acute Coronary Syndrome } & \multirow[t]{3}{*}{ Total } & \multirow[t]{3}{*}{ P-Value } & \multirow[t]{3}{*}{$\mathbf{O R}$} \\
\hline & & \multicolumn{2}{|c|}{$U A P$} & \multicolumn{2}{|c|}{ NSTEMI } & \multicolumn{2}{|c|}{ STEMI } & & & \\
\hline & & $N$ & $\%$ & $N$ & $\%$ & $N$ & $\%$ & & & \\
\hline \multirow{4}{*}{$\begin{array}{l}\text { Degree of } \\
\text { Hypertension }\end{array}$} & Normal-High & 10 & 52,63 & 5 & 26,32 & 4 & 21,05 & 19 & \multirow[t]{5}{*}{0,000} & 0.014 \\
\hline & Hypertension grade I & 15 & 62,50 & 5 & 20,83 & 4 & 16,67 & 24 & & 0.938 \\
\hline & Hypertension grade II & 7 & 24,14 & 18 & 62,07 & 4 & 13,79 & 29 & & 0.938 \\
\hline & Hypertension grade III & 5 & 12,50 & 6 & 15,00 & 29 & 72,50 & 40 & & 1.875 \\
\hline \multicolumn{2}{|l|}{ Total } & 37 & 33,40 & 34 & 30,36 & 41 & 36,61 & 112 & & \\
\hline
\end{tabular}

In table 6 , it was obtained from the number of 112 subjects studied, it was found that 19 patients in the Cardiac Inpatient Room of Dustira Cimahi Hospital with normal-high blood pressure were 10 people $(52.63 \%)$ including UAP, from 24 patients with grade I hypertension as many as 15 people $(62.50 \%)$ included STEMI, 18 of the 29 patients with grade II hypertension $(62.07 \%)$ included NSTEMI, and 29 of the 40 patients with grade III hypertension $(72.50 \%)$ included STEMI. Based on the results of research on the degree of hypertension on the incidence of ACS carried out at the Internal Medicine Department of Bethesda Tomohon Hospital in NovemberDecember 2013, it was obtained from 44 patients diagnosed with ACS, as many, as 7 people did not have a history of hypertension (15.9\%), 9 people were prehypertensive. (20.5\%), 9 people with grade 1 hypertension (20.5\%), and 19 people with grade 2 hypertension (43.2\%). Based on the number, STEMI is the most cases, followed by NSTEMI, and finally unstable angina pectoris (APTS). Increased systolic and diastolic blood pressure increases the risk of developing ACS. Individuals with blood pressure above $160 / 95 \mathrm{mmHg}$ have a 23 times greater risk of developing ACS [23-26].

The state of obesity and DM can also affect the patient's condition which in turn affects the diagnosis of the classification of ACS that occurs. This study was conducted to find out the coherence between the degree of hypertension and the incidence of ACS in the absence of other comorbidities in the patient.

Based on the results of statistical tests, the value of $\mathrm{p}=$ 0,000 was obtained, where the higher the degree of hypertension, the more likely it is to be exposed to ACS so that there is a significant coherence between the degree of hypertension and the incidence of ACS in the Cardiac Inpatient Room of Dustira Cimahi Hospital in 2018 because the p-value is smaller than $5 \%$. $(0.000<0.05)$.

Based on the Odds Ratio, it was found that patients with normal-high blood pressure had the risk of experiencing ACS incidence of 0.014 times, grade I and II hypertension had the risk of experiencing ACS incidence of 0.938 times, while grade III hypertension had the highest risk of experiencing ACS incidence of 1.875 times.

\section{CONCLUSION}

Based on the results of research that has been carried out regarding the coherence between the degree of hypertension and the incidence of acute coronary syndrome in the Cardiac Inpatient Room of Dustira Cimahi Hospital in 2018 with a total of 112 subject medical records that meet the research inclusion criteria of a total of 1,580 ACS patients in 2018, the conclusions are:

- There were 37 subjects $(33.00 \%)$ with a diagnosis of UAP, 34 subjects $(30.40 \%)$ with a diagnosis of NSTEMI, and 41 subjects $(36.60 \%)$ with a diagnosis of STEMI in hypertensive patients at Dustira Cimahi Hospital in 2018.

- There were 19 subjects $(17.00 \%)$ with normal-high blood pressure, 24 subjects $(21.40 \%)$ with grade I hypertension, 29 subjects $(25.90 \%)$ with grade II hypertension, and 40 subjects $(35.70 \%)$ grade III hypertension in ACS patients at Dustira Cimahi Hospital in 2018.

- There is a significant coherence between the degree of hypertension and the incidence of acute coronary syndrome in the Cardiac Inpatient Room of Dustira Cimahi Hospital in 2018.

\section{REFERENCES}

[1] J. Loscalzo, Harrison's cardiovascular medicine 2/E. McGraw-Hill Education, 2013.

[2] B. Nuraini, "Risk factors of hypertension," Jurnal Majority, vol. 4, pp. 10-19, 2015.

[3] Kemenkes RI, INFODATIN Pusat Data dan Informasi Kementrian Kesehatan RI. Jakarta: Kemenkes RI, 2014, p. 1-6.

[4] Perhimpunan Hipertensi Indonesia, Hari Hipertensi sedunia. Jakarta: Perhimpunan Hipertensi Indonesia, 2019, p. 3-4.

[5] Departemen Kesehatan Republik Indonesia, Pharmaceutical Care untuk Penyakit Hipertensi. Jakarta: Direktorat Bina Farmasi Komunitas dan Klinik, 2006

[6] J. Martin, "Hypertension Guidelines: Revisiting the JNC 7 Recommendations," The Journal of Lancaster General Hospital, vol. 3, pp. 91-97, 2008.

[7] PERKI, Pedoman Tatalaksana Sindrom Koroner Akut. Jakarta: PERKI, 2018, p. 1-44.

[8] E. Braunwald, Braunwald's Heart Disease, Edisi Delapan. Philadelphia: Saunders Elsevier, 2008; p. 1207-31.

[9] A. Kumar, and C.P. Cannon, “Acute coronary syndromes: diagnosis and management, part I," In Mayo Clinic Proceedings (Vol. 84, No. 10, pp. 917-938). Elsevier, 2009. 
[10] P.T. O'gara, F.G. Kushner, D.D. Ascheim, D.E. Casey, M.K. Chung, J.A. De Lemos, and D.X. Zhao, "2013 ACCF/AHA guideline for the management of ST-elevation myocardial infarction: a report of the American College of Cardiology Foundation/American Heart Association Task Force on Practice Guidelines," Journal of the American college of cardiology, vol. 61, pp. e78-e140, 2013.

[11] R. Kriswiatiny, Z. Mandala, and M. Efendy, "Hubungan Infark Miokard Akut (Ima) Yang Dirawat Inap Dengan Hipertensi Di Rsud Dr. H. Abdulmoeloek Provinsi Lampung Tahun 2014 \& 2015," Jurnal Ilmu Kedokteran dan Kesehatan, vol. 3, 2016.

[12] D.E. Wahyuni, "Hubungan Tingkat Pendidikan dan Jenis Kelamin Dengan Kejadian Hipertensi Di Kelurahan Jagalan di Wilayah Kerja Puskesmas Pucangsawit Surakarta," Jurnal Ilmu Keperawatan Indonesia, vol, 1, pp. 113, 2013.

[13] A.D. Anggraini, A. Waren, E. Situmorang, H. Asputra, S.S. Siahaan, Faktor-faktor yang berhubungan dengan kejadian hipertensi pada pasien yang berobat di poliklinik dewasa puskesmas Bangkinang periode januari sampai juni 2008. Riau: Universitas Riau, 2009.

[14] S. Aprianti and M. Arif, "Nilai Small Dense LDL Remaja Dan Kaitannya Dengan Lipid Lainnya," Indonesian Journal Of Clinical Pathology And Medical Laboratory, vol. 13, pp. 17-19, 2018.

[15] K. Cortas, Hypertension.[serial online]. The Journal of Public Health http://www. emedicine. com [28 Desember 2017], 2008.

[16] Z. Agustini, Hubungan asupan lemak (lemak jenuh, tak jenuh, kolesterol) dan natrium terhadap tekanan darah pada pasien hipertensi di poli penyakit dalam rsp batu. Malang: Universitas Brawijaya, 2013.

[17] E. Rahajeng and S. Tuminah, "Prevalensi hipertensi dan determinannya di Indonesia," Majalah Kedokteran Indonesia, vol. 59, pp. 580-587, 2009.
[18] H.J. Sigarlaki, "Karakteristik dan faktor berhubungan dengan hipertensi di desa bocor, kecamatan bulus pesantren, kabupaten kebumen, jawa tengah, tahun 2006," Makara, Kesehatan, vol. 10, pp. 78-88, 2006.

[19] S.R. Torry, L. Panda, and J. Ongkowijaya, "Gambaran faktor risiko penderita sindrom koroner akut," E-clinic, vol. 2, 2014.

[20] P.C. Van den Hoogen, E.J. Feskens, N.J. Nagelkerke, A. Menotti, A. Nissinen, and D. Kromhout, "The relation between blood pressure and mortality due to coronary heart disease among men in different parts of the world," New England Journal of Medicine, vol. 342, pp. 1-8, 2000.

[21] S. Setiati, I. Alwi, A.W. Sudoyo, K. Simadibrata, B. Setiyohadi, and A.F. Syam, Buku ajar ilmu penyakit dalam. Jakarta. FKUI; 2015, p. 1367- 1381, 2016.

[22] H. Halimuddin, "Tekanan Darah dengan Kejadian Infark Pasien Acute Coronary Syndrome,” INJ, vol. VII, no. 3, pp. 32-33, 2016.

[23] A. Mawardy, J.A. Pangemanan, and D.U. Djafar, Gambaran Derajat Hipertensi Pada Pasien Sindrom Koroner Akut (SKA) di RSUP PROF. R. D. Kandou Manado Periode Januari - Desember, 2014, p. 7-9.

[24] P.R. Moreno, V.H. Bernardi, and J. López-Cuéllar, "Macrophages, smooth muscle cells, and tissue factor in unstable angina: implications for cell-mediated thrombogenicity in acute coronary syndromes," vol. 94, pp. 3090-7, 1996.

[25] A.J. Fosang, and P.J. Smith, "Human genetics: to clot or not," Nature, vol. 413, pp. 475-6, 2001.

E.J. Weiss, P.F. Bray, and M. Tayback, “A polymorphism of a platelet glycoprotein receptor as an inherited risk factor for coronary thrombosis," N Engl J Med., vol. 334, pp. 1090-4, 1996. 